University of Michigan Law School

University of Michigan Law School Scholarship Repository

Articles

Faculty Scholarship

1911

\title{
The Corporation Tax Decision
}

Ralph W. Aigler

University of Michigan Law School

Available at: https://repository.law.umich.edu/articles/1113

Follow this and additional works at: https://repository.law.umich.edu/articles

Part of the Business Organizations Law Commons, Constitutional Law Commons, Supreme Court of the United States Commons, and the Taxation-Federal Commons

\section{Recommended Citation}

Aigler, Ralph W. "The Corporation Tax Decision." Mich. L. Rev. 9 (1911): 595-9.

This Response or Comment is brought to you for free and open access by the Faculty Scholarship at University of Michigan Law School Scholarship Repository. It has been accepted for inclusion in Articles by an authorized administrator of University of Michigan Law School Scholarship Repository. For more information, please contact mlaw.repository@umich.edu. 


\section{Michigan LaW REvieW}

PUBLISHED MONTHLY DURING THE ACADEMTC TEAR, ExcroSIVA OF OCTOBER, BY THE - LAW FACULTY OF the UNIVERSITY OF MICHICAN

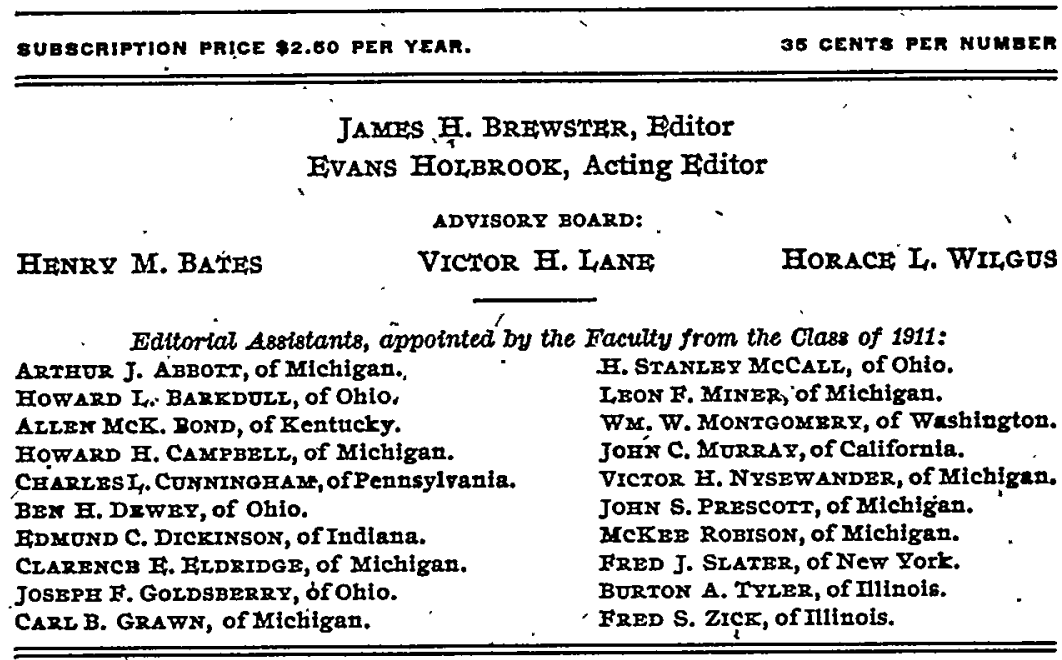

\section{- NOTE AND COMMENT.।}

The Corporation TAx Decision.-Seldom, if ever, in the history of the country has the. Supreme Court been called upon within a comparatively short period of time to decide so many questions of widespread interest and vital importance as has been the case during the last year or two. Attempts on the part of the state and national governments to regulate and control corporations, which in recent years have come to exercise suclt $a^{\circ}$ large and not always wholesome influence upon affairs generally, have been the occasion for the consideration by the court of many of the important cases recently presented. Among these are the so-called "Corporation Tax Cases," reported in '3I Sup. Ct. 342, under the name of Flint v. Stone Tracy Co. In newspapers and periodicals, legal and otherwise, the questions involved attracted a great deal of attention, and many articles pro and con as to the constitutionality of the tax were prepared and printed. That the members of the court themselves considered the questions as of great and vital importance is evidenced by the fact that when the court's numbers had been reduced by death and resignation a reargument of the cases was ordered so that the decision might be by the full bench, although apparently the re- 
maining members of the court were unanimous in considering. the tax valid.

Section 38 of the Act of Congress approved August 5, 1909, which contains the corporation tax law, provides as follows: "Every corporation, joint stock company or association, organized for profit and having a capital stock represented by shares, and every insurance company $* * *$ shall be subject to pay annually a special excise tax with respect to the carrying on or doing business by such corporation, joint stock company or association or insurance company equivalent to one per centum upon the entire net income over and above five thousand dollars received by it from all sources during such year, exclusive of amounts received by it as dividends upon stock of other corporations, joint stock companies or associations or insurance companies subject to the tax hereby imposed, etc." The validity of the provision was challenged on every ground that able and astute counsel could suggest. Mr. Justice DAY in an opinion concurred in by all the members of the court disposed of all the objections raised, and in unmistakable terms declared the power of Congress to levy a tax of the nature under consideration.

After shortly disposing of the contention that Section 38 did not originate in the House as required by $\S 7$ of Article I of the Constitution, and after having reached the conclusion that the true construction of the Act is "that the tax is imposed not upon, the franchises of the corporation, irrespective of their use in business, nor upon the property of the cotporation, but upon the doing of corporate or insurance business, and with respect to the carrying on thereof, in a sum equivalent to I per centum, etc.," the court proceeded to a consideration of the constitutionality of the provision. A number of the-supposed objections were discussed, the chief ones being the following: ( $I$ ) that the tax is "direct" within the rule as laid down in the income tax cases and therefore requires apportionment; (2) that there is an interference with or infringement of the sovereignty of the states, in that it taxes the exclusive right of the states to create corporations; and (3) that the tax is arbitrary and unjust.

As to the first objection the court pointed out that the tax is not a tax upon property solely because of its ownership, that "In the present case the tax is not payable unless there be a carrying on or doing of business in the designated capacity," which "is made the occasion for the tax, measured by the standard prescr bed." It is pointed out that the tax under consideration in the income tax cases was held direct "because imposed upon property solely by reason of its ownership." a tax upon the income of property being equivalent to a tax upon the property itself, but that the power of the Federal government to tax business, privileges and employments had been therein expressly conceded. Thus it being determined that the corporation tax is a tax upon the privilege of doing business in a corporate capacity, the income tax cases instead of being authority against the validity of the tax are in their dicta at least authority for its constitutionality. Reference was made to Knowlton v. Moore, I78 U. S. 4I, 44 L. ed. 969, 20 Sup. Ct. 747, and to Spreckels Sugar Refining Co. v. McClain, 192 U. S. 397, 48 . L. ed. 496, 24 Sup. Ct. 376 , as taking the same view of the income tax cases. Having reached the conclusion that the tax does not lay a burden upon real or personal property 
because of its ownership and so therefore not a "direct" tax, it was unnecessary for the court to go further in classifying the tax, for under the Constitution only capitation and direct taxes need be apportioned. The court however adde'd that the tax imposed is an "excise," and in support of this conclusion cited and quoted from the opinion of Mr. Chief Justice FULIER in one of the income tax cases (157 U. S. 557), the opinion of the same Chief Justice in Thomds v. United States, 192 U. S. 363, $48 \mathrm{I}$. ed. 48I, 24 Sup. Ct. Rep. 305, and from Cooley, Const. Lim., E.d. 7, 680.

The suggestion that the tax in order to be upheld' must be apportioned - is based upon an express constitutional limitation of the power of Congress to levy taxes, but as has been seen there is no necessity for the apportionment of the tax under.consideration for the reason that it is not a "direct" tax. The second objection, above stated that the tax is bad because it lays a tax upon the exclusive right of a state to grant corporate franchises, in that it taxes franchises which are the creation of the state in its sovereign right and authority is rested upon the implied limitation upon the powers of the national and state governments to take action which encroaches upon or cripples the exercise of the exclusive power of scvereignty in the other. After reviewing the cases Mr. Justice DAY said: "The cases unite in exempting from Federal taxation the means and instrumentalities employed in carrying on the governmental operations of the state. The exercise of such rights as the establishment of a judiciary, the employment of officers to administer and execute/the laws, and similar governmental functions, cannot be taxed by the Federal government. The Collector v. Day, in Wall. Ir3, 20 L. ed. I22; United States v. Baltimore \& $O$. $R$. Co., I7 Wall. 322, 21 L. ed. 597; Ambrosini v. United States, I87 U. S. I, 47 L. ed. 49, 23 Sup. Ct. I, I2 Am. Crim. Rep. 699. But this limitation has never been extended to the exclusion of the activities of a merely private business from the Federal taxing power, although the power to exercise them is derived from an act of incorporation by one of the states. We therefore reach the conclusion that the mere fact that the business taxed is done in pursuance of authority granted by a state in the creation of private corporations does not exempt it from the exercise of Federal authority to levy excise taxes upon such privileges." It was also urged that the tax imposed was invalid because Congress might so exercise its power, if the power of the Federal government to levy such a tax be found to exist, that the right of the states to create corporations would be practically destroyed. Mr. Justice DAX answered this argument with the observation that where a tax is levied upon a proper subject of taxation it cannot be urged as an objection to the validity of such tax that the power may be so exercised as to become oppressive or that the subject of the tax may be thereby destroyed. "The remedy for such wrongs, if such in fact exist, is in the ability of the people to choose their own representatives, and not in the exertion of unwarranted powers by courts of justice." This argument perhaps should not be discussed under the interference-with-sovereignty objection. There could be no interference with the sovereign right of the states to create corporations, and such is not the effect of the corporation tax even though the tax were of such an amount as to drive 
corporations out of existence; the tax operates not upon the creation of corporations but upon the corporation after it has come into existence, and not then unless it is carrying on business.

It was also insisted that the tax is "so unequal and arbitrary in the fact that it taxes a business when carried on by a corporation, and exempts a similar business when carried on by a partnership or private individual, as to place it beyond the authority conferred upon Congress." To this argument Mr. Justice DAY said: "As we have seen, the only limitation upon the authority conferred is uniformity in laying the tax, and uniformity does not require the equal application of the tax to all persons or corporations who may come within its operation, but is limited to geographical uniformity throughout the United States." The court then considered the effect of the I 4 th Amendment upon uniformity in taxation and upon the classification of subjects of taxation, and pointed out that the amendment applies only to state legislation. And "it could not be said, even if the principles of the 14th amendment were applicable to the present case, that there is no substantial clifference between the carrying on of business by the corporations taxed, and the same business when conducted by a private firm or individual." If the tax were upon business, then it might properly be said that a classification so as to impose the burden only upon corporations would be arbitrary, for business is the same whether carried on by individual, firm or corporation. But the corporation tax is not upon business but upon the privilege of doing business in a corporate capacity, and there is a clear difference between the right to engage in or carry on business as an individual or firm and as a. corporation with all the rights and privileges that come with incorporation. This distinction is pointed out by Mr. Justice Day. Even if the tax were upon business and even if it be conceded that a classification so as to burden only corporations with its payment would be arbitrary 'n the sense that the business is the same whether carried on by an individual or corporation, it is by no means clear that the court would be warranted in declaring the tax unconstitutional, for business is a proper subject of taxation and geographical uniformity is the only uniformity required by the Constitution.

A number of other arguments against the constitutionality of the tax were considered by the court. It was pointed out that so long as the tax was upon a subject within the power of the Federal government to tax, it was no objection thereto that the basis of measurement was the income received from all sources, that on the contrary that method of measurement was perhaps the most satisfactory and just. That in the income used as the basis of measurement might be included interest upon government and municipal bonds and other non-taxable securities and the receipts from real and personal property not used in the business was held to be unobjectionable. It was also held that public service corporations and corporations engaged in such activities as leasing property, collecting rents, managing office buildings, making investments of profits, or leasing ore lands and collecting royalties, managing wharves, dividing profits, and in some cases investing the surplus, are engaged in business within the meaning of the statute and subject to the tax. 
In the January (19I0), number of this Review (8 MicH. L. REv. 204), there was published an article on "The Constitutionality of the Federal Corporation Tax." This article was reprinted in 40 National Corporation Reporter 798. The conclusions there reached are substantially in accord with the view taken by the Supreme Court.

R. W. A. 